\title{
Benin and Western Nigeria Offshore Basins: A Stratigraphic Nomenclature Comparison
}

\author{
Gérard Alfred Franck d'Almeida1 ${ }^{*}$, Christophe Kaki'1 ${ }^{1}$ James Adejimi Adeoye ${ }^{2}$ \\ ${ }^{1}$ Department of Earth Sciences, University of Abomey-Calavi, Cotonou, Benin \\ ${ }^{2}$ Department of Geology and Mineral Sciences, University of Ilorin, Ilorin, Kwara State, Nigeria \\ Email: *almeidafranck@hotmail.com
}

Received 5 January 2016; accepted 26 February 2016; published 29 February 2016

Copyright (C) 2016 by authors and Scientific Research Publishing Inc.

This work is licensed under the Creative Commons Attribution International License (CC BY).

http://creativecommons.org/licenses/by/4.0/

(c) (i) Open Access

\section{Abstract}

The Benin and Western Nigeria Offshore Basins, which are parts of an extensive basin called the Dahomey (Benin) Embayment, were formed during the Early Cretaceous under similar tectonic conditions and continental sedimentary environments. Based mainly on available lithological, biostratigraphic and paleoenvironmental data, this paper summarizes the stratigraphic succession of theses basins and attempts a comparison of these stratigraphic nomenclatures. The bulk of data shows that sedimentation begins with terrestrial at the base, passes through shallow marine, deep marine (with restrictive bottom circulation) and ends with open deep marine conditions. The stratigraphy of the Offshore Benin Basin was established later and considering lithological and paleontological similarities with formations of various southern Nigeria basins, the stratigraphic chart adopted for this basin was a mixed variant of various Southern Nigerian basins nomenclatures. For the first time, a correlation of stratigraphic charts of each basins and a schematic cross section showing their lithostratigraphic units, especially the Cretaceous-Paleocene interval which is petroliferous, are proposed. The study shows that the nomenclature adopted in Benin Republic must be revised by using type section/locality names for some particular Formations and widely accepted Formations names of Nigeria for the others. This will permit to avoid confusions as it is presently the case for the name "Afowo Formation" representing a Cretaceous sequence in Nigeria and which is use in Benin Republic to distinguish some sediments of Miocene age. Moreover, a High Resolution Biostratigraphy summary (including micropaleontology, nannopaleontology and palynology distributions) relating to each offshore basin is needed for sequences correlations and entire harmonization of the stratigraphic nomenclature of these offshore basins.

\section{Keywords}

Benin, Western Nigeria, Offshore Basins, Stratigraphy, Stratigraphic Nomenclature, Comparison

\footnotetext{
"Corresponding author.
} 


\section{Introduction}

The Dahomey (Benin) Embayment is part of a system of West African peri-cratonic (margin sag) basin [1]-[4], covering much of the continental margin of the Gulf of Guinea, extending from Volta-delta in Ghana on the West to the Okitipupa Ridge in Nigeria on the East (Figure 1). The Romanche (apparently an offset extension of the Ghana Ridge) and Chain (supposedly an offset extension of the Benin Hinge Line) fractures zones delimited the Dahomey Embayment which was formed during the opening of Equatorial Atlantic starting in the Late Jurassic and continuing into the Cretaceous [5]-[11]. The crustal separation, typically preceded by crustal thinning, was accompanied by an extended period of thermally induced basin subsidence through the Middle-Upper Cretaceous to Tertiary times as the South American and the African plates entered a drift phase to accommodate the emerging Atlantic Ocean [12]. The onshore part of the basin has covers a broad arc-shaped profile of about 600 $\mathrm{km}^{2}$ in extent, and a maximum width of some $130 \mathrm{~km}$, along its N-S axis, near the Nigerian-Republic of Benin border. The study area is located between longitudes $2^{\circ} 30^{\prime}$ and $3^{\circ} 20^{\prime} \mathrm{E}$ and latitudes $7^{\circ} 40^{\prime}$ and $7^{\circ} 52^{\prime} \mathrm{N}$, and lies in the offshore zone (see Figure 1). The offshore stratigraphy of separate basins of the Dahomey Embayment has been described by various workers [1]-[4] [6] [7] [9] [10] [13]-[18]. However, few studies have been conducted in terms of comparison of the stratigraphic nomenclature of different offshore sectors of this extensive basin [19].

The present study examines the stratigraphic succession of Benin and Western Nigeria Offshore Basins and attempts to compare these stratigraphic nomenclatures. It is a preliminary stage process aiming to give additional information for the beginning of a Stratigraphic Harmonization Project concerning sedimentary basins of the West Africa Zone (Benin, Cote d’Ivoire Ghana, Western Nigeria and Togo).

\section{Stratigraphy of Western Nigeria Offshore Basin}

The stratigraphy of the eastern Dahomey basin has been studied and discussed by various authors [1] [11] [13] [14] [20]. The recent classification schemes are shown in Table 1.

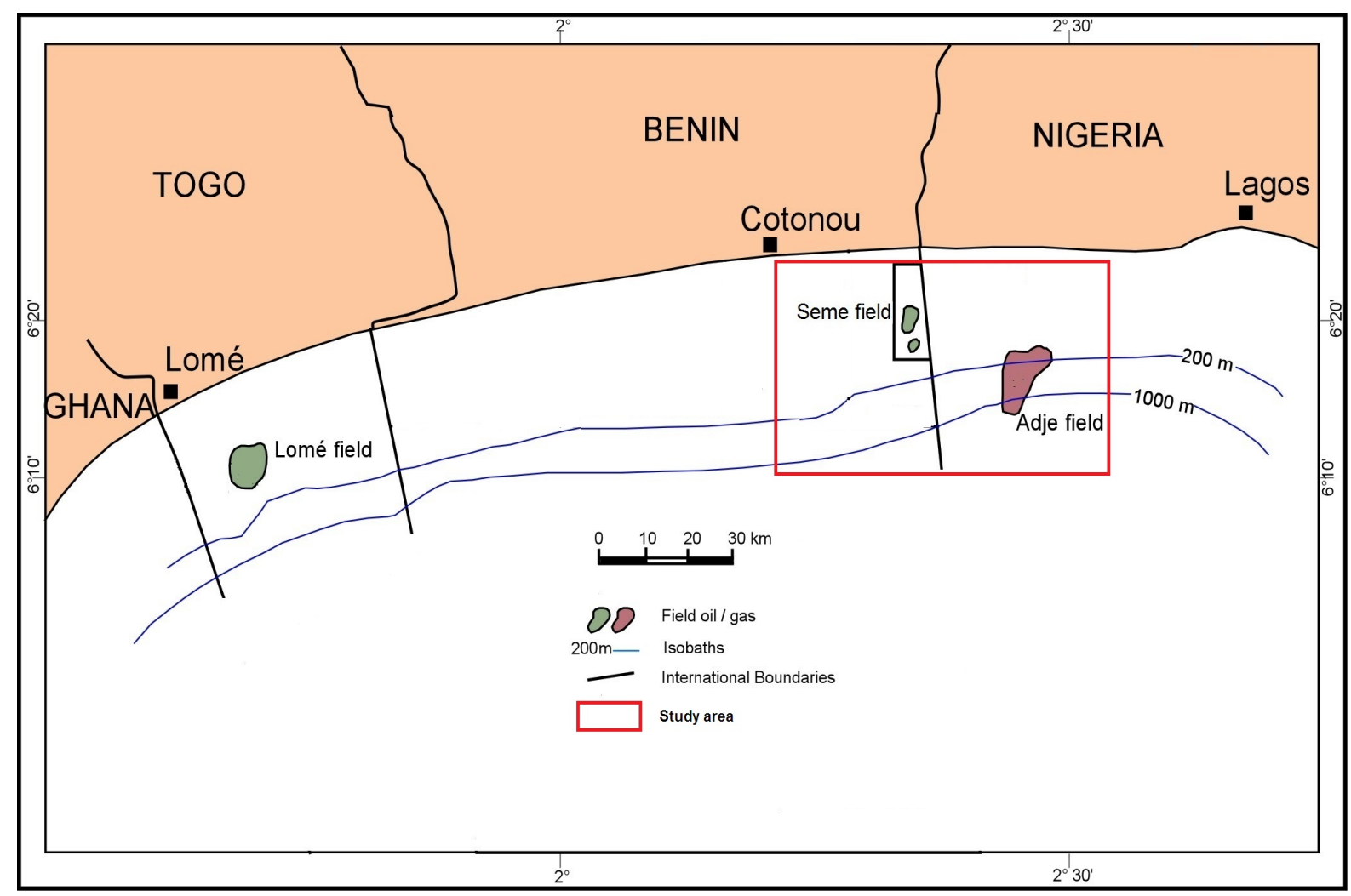

Figure 1. Dahomey Embayment with indication of the study area. 
Table 1. Stratigraphic chart of the Southwestern Nigeria Basin.

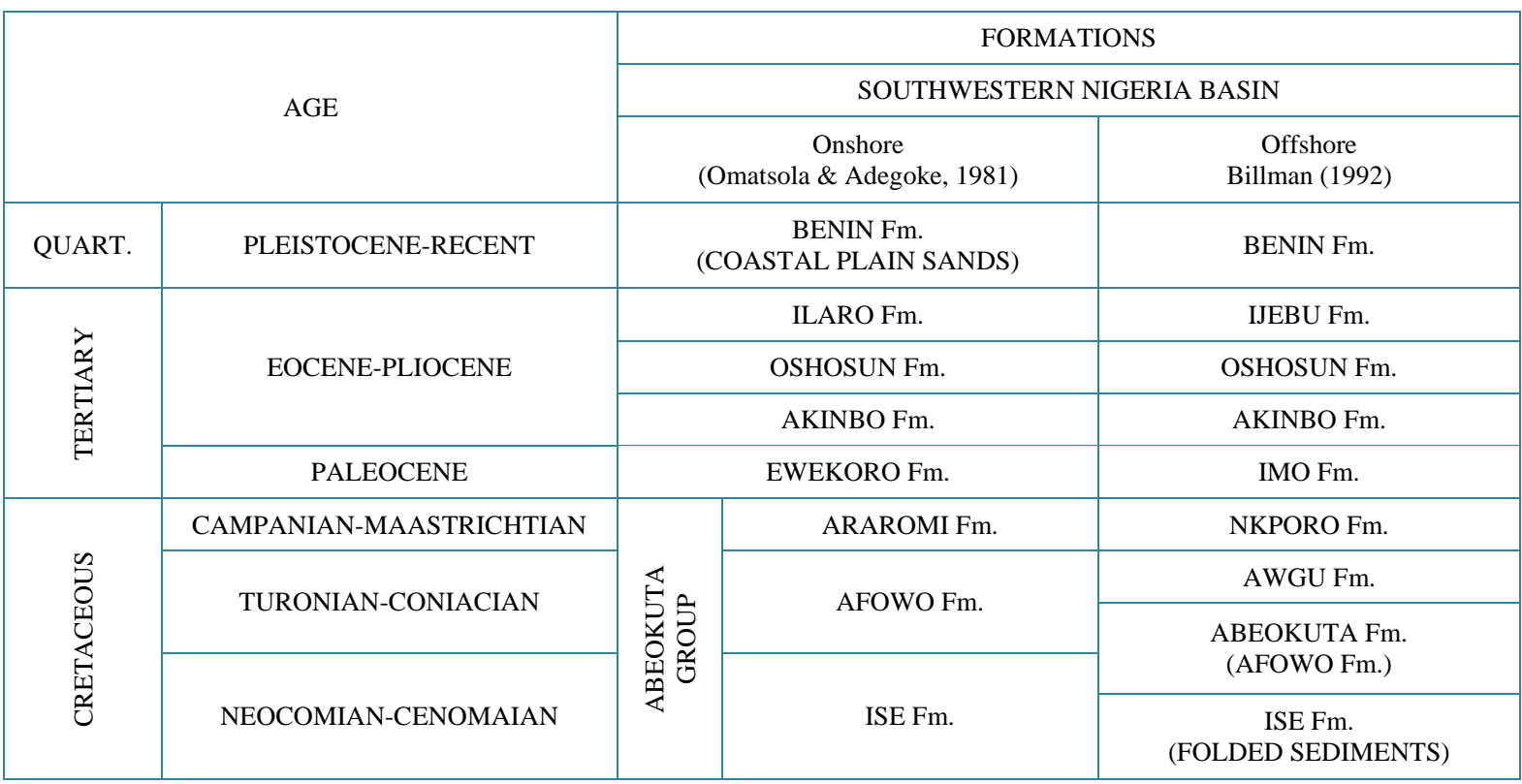

The stratigraphic sequence spans from Cretaceous to Recent. This includes the Cretaceous Abeokuta Group which comprises Ise, Afowo and Araromi Formations; the Paleocene Ewekoro Formation; the Late Paleocene to early Eocene Akinbo Formation; the Eocene Oshosun and Ilaro Formations and the Pleistocene to Recent Benin Formation [11] [12] [14] [18]. Based additionally on recent works [7] [21]-[23], a regional stratigraphic summary for the entire Western Nigeria coastal basin is presented below:

\subsection{Ise Formation}

This formation uncomformably overlies the basement rocks and consists of a basal conglomerates overlain by coarse to medium grained loose sands, sandstones and grits containing kaolinitic clays. The conglomerates are imbricated and somewhere ferruginous. The Shell-BP geologists recovered from Ise-2 borehole, some sporomorphs including Cicatricosisporites sp., pilosisporites, trichopapillosus, etc. and these assemblages indicate a Neocomian, probably Valanginian-Barremian age [11].

\subsection{Afowo (Abeokuta) Formation}

In Southwestern Nigeria, Afowo Formation is the main petroliferous Formation. It overlies the Ise formation and consists of coarse to medium grained sandstones with thick intercalations of shales, siltstones and pyritised clay. According to [11], the basal part of the formation consists of well sorted subrounded fluviatile sand with mixed brackish to marine sediments. This formation was assigned a Turonian age by [13] on the basis of palynological assemblages which include Elytranthe subzone and Multiporopollenites aff. M. maculosus zone. It has been assigned a Late Cenomanian-Santonian age on the basis of palynology [21] [22] and a Cenomanian-Coniacian age on the base of occurrence of planktonic foraminifera Rotalipora Greenhornensis (Present study).

\subsection{Araromi (Nkporo) Formation}

Araromi Formation conformably overlies the Afowo Formation. From bottom to top, it is composed of fine-medium grained sandstone overlain by shales, siltstones with limestones inclusions, marls and lignite. The shales are dark to black and contain abundant planktonic and benthic foraminifera (Globorotalia mayaroensis and Globotrucana stewartiformis), ostracods, pollens and spores. The dark shale unit in the Western Nigeria offshore basin is correlated with the Nkporo Shale in the Anambra Basin by [13]. Therefore, the Npkoro shale, as it named by [13], is partially equivalent to the Araromi Formation. Based mainly on faunal content, a Maastrichtian to Paleocene age is given to this Formation [11] [21]. 


\subsection{Ewekoro Formation}

The Ewekoro Formation overlies the Abeokuta Group. Four carbonate microfacies have been described. This consists of a sandy biomicrosparite, shelly biomicrite, red phosphatic biomicrite and algal biosparite with abundant skeletal debris. The structure and texture of the limestones indicate a shallow marine environment of deposition. [22] reported a dominance of macrofaunas by molluscs especially nautiloids, pelecypods, gastropods and scaphopods and sizable coral fauna. The occurrence of Globorotalia acuta, Globorotalia velascoensis, Globigerina trigoculinoids and Globorotalia pseudobulloides, in Ewekoro Formation suggest a Paleocene age.

Palynomorph assemblages indicate also a Paleocene age [21]. Furthermore, the radioactive age of glauconite overlying the limestone and those within the shale indicate a $54 \pm 2.7$ Ma age (not younger than Paleocene).

\subsection{Akinbo Formation}

The Akinbo Formation lays uncomformably on the Ewekoro Formation. Some glauconitic bands with lenses of limestones occur at the basal part. The top of the formation is pure grey, gritty sand with little clay. The claystones are rich in kaolinitic concretions. The formation is Upper Paleocene to Lower Eocene in age [20]. Akinbo Formation is not always distinguished and separated from Oshosun Formation.

\subsection{Oshosun Formation}

Above the Akinbo Formation is the Oshosun Formation which consists of various colored laminated and glauconitic clay and shale with sandstones intercalations [20]. The Formation is phosphate-bearing. [23] described the fossil assemblage as consisting of molluscs, corals, pelagic and planktonic foraminifera. Basing on palynology assemblage a Lower Eocene-Middle Eocene age is give to this Formation [21]. Fishes and sea snakes in the shale specify that the Formation was deposited in a marine environment.

\subsection{Ilaro (Ijebu) Formation}

The Formation consists of massive, poorly consolidated; cross-bedded sandstones which conformably overlie the Oshosun Formation. Subrounded to rounded pure quartz grains dominate the base of the formation. This texture indicates a beach or shoreline and nearshore environment. The formation is sparsely fossiliferous but the occurrences of some benthic foraminifera have been described. This formation was assigned an Eocene-Oligocene age.

\subsection{Benin Formation}

The Benin Formation, also called the Coastal Plain Sands [11], consists of poorly sorted sands with lenses of clays. The sands are in parts cross-bedded and show nearshore to continental distinctiveness. The Formation age covers the Miocene to Recent periods.

Finally, it is imperative to precise that palynological studies of [23] and [22], related respectively to Tertiary and Cretaceous sediments, provide significant additional information in the understanding of Western Nigeria offshore basin stratigraphy. The results of these studies (particularly Palynomorph assemblages and identified biozones) will be useful for sediments age and linked depositional environments appraisal in Benin part.

\section{Stratigraphy of Benin Offshore Basin}

The stratigraphy of the Offshore Benin Basin has been discussed by various workers and ranges from Neocomian (Ise Formation) to Recent (Benin-Ijebu Formation) [1] [9] [11]-[14] [16] [19] [24]-[27] (Figure 2). Below are done the Formations characteristics as summarized in one of my previous recent publication [9].

\subsection{Ise Formation}

Ise Formation consists of conglomerates, sandstones, shales and minor carbonate. The sandstone is white to light grey, medium to coarse, unsorted, conglomeratic, quartzic, well indurate, containing mica and chlorite, kaolinite and some carbonate cement [9]. The shale is grey, brown, fissile and hard [24]. Datation based on spore and pollen was provided but was unsuccessful because the formation is much damaged [9]. An early Cretaceous 
(Neocomian) age is assigned to this formation by comparison with western Nigeria and due to the presence of Cicatricosisporites sp. Flora [11].

\subsection{Albian Sandstone}

The name "Albian Sandstone" has been used by [13] [14]. The lithology of this unit is predominantly sandstone with frequent shaley and dolomitic layers, which distinguishes it from the overlying unit. The sandstones are white, grey to dark brown, fine to coarse grained, fair to poor sorting, feldspathic and micaceous [9]. The palynological assemblage of this unit (Pelletieria minutaestriata, Araucariacites australis, Cicatricosisporites sp. cf. hallei, Classopollis sp., Gnetaceaepollenites cf. complex and Cycadopites sp.), suggests an Albian age.

\subsection{Abeokuta Formation}

The Abeokuta Formation consists of sandstones and conglomerates with thin layers of silty sand or shales. The sandstones are light grey to white, generally coarse grained, poorly sorted and with abundant pyrite. Species and generic diversities of ostracods fauna, echinoids and gastropods are common (Brachycythere angulata, Ovocytheridea sp. and Clithrocytheridea senegali). The palynological assemblage (Multiporopollenites maculosis and Converrucosisporites sp.) suggests a Cenomanian-Turonian to Early Senonian age.

\subsection{Awgu Formation}

This formation consists of sequence of anaerobic marine dark grey calcareous shales, occasionally containing calcareous siltstone and more rarely fine-grained sandstones. Faunally, benthic foraminifera are dominant with species diversity while planktic, very diagnostic, are restricted [9]. A Coniacian to Maastrichtian age is given to the Formation [14].

\subsection{Araromi Formation}

Araromi Formation comprises dark laminated carbonaceous shales with abundant pyrite and poor preserved pyritised microfauna (planktonic and benthic foraminifera, ostracods) [9]. Planktonic foraminifera (Rugoglotrucana rugosa and Rugoglobigerina scotti) are frequents while Globotrucana arqua and Globotrucana sp. are only some. These planktonic foraminifera are correlated with those of undifferentiated zones containing Globorotalia mayaroensis and Globotrucana stewartiformis. Limestone occurs frequently. Here, the Araromi Formation is subdivided into an upper and lower member and a Maastrichtian to Early Paleocene age is assigned to this Formation.

\subsection{Imo Formation}

The Imo Formation consists of light greenish to bluish, grey to dark grey, non calcareous, firm to moderately hard shales with stringers of dark grey, microcrystalline limestone [9]. This shale grades downwards to a yellow and pale grey limestone rather shale laminated. Shale and limestone constitutes a mega sequence, several time repeated all way down. Benthic foraminifera like Bolivina Africana and Anomalina midwayensis were identified within shales units. The age of this Formation ranges from Middle Paleocene to Early Eocene.

\subsection{Oshosun Formation}

The Formation consists of sandy, varied colored and phosphatic claystones grading to siltstone [9]. Both onshore and offshore data points to a Middle Eocene age.

\subsection{Afowo Formation}

The Afowo Formation is subdivided two units being separated by an unconformity named Mid Miocene Unconformity. The Upper Afowo unit is a sequence of grey brown soft, sticky and silty clay interbedded with friable, coarse-grained sandstone with glauconite, pyrite and shell debris. The lower Afowo unit is described as a light grey siltstone grading upwards to fine grained sandstone but becoming claystones towards the [9]. Typical of the Lower Afowo is the salt and pepper texture. The characteristic foraminifer fossil encountered, Bolivina 
imperatris, concur to assign an Early to Middle Miocene age to this Formation [13].

\subsection{Benin-Ijebu Formation}

The uppermost unit in the offshore Benin basin is named Benin-Ijebu Formation. It is usually coarse-grained marine shelf sands. Palynology reveals the presence of Ilex and Alux genres indicating an Upper Miocene to Recent age for this lithostratigraphic unit.

The general tectono-stratigraphic chart of the Offshore Benin Basin with indication of seismic boundaries of the Formations is presented below (Figure 2).

\begin{tabular}{|c|c|c|c|c|c|c|c|}
\hline$\frac{\text { SYSTE M }}{\text { PER IOD }}$ & ЕРОСН & AGE & FORMATION & LITHOLOGY & \begin{tabular}{|l|} 
STRUCTURAL \\
SUBDIVISION \\
\end{tabular} & $\begin{array}{c}\text { DEPOSITIONAL } \\
\text { SUBDIVISION }\end{array}$ & \begin{tabular}{|l|} 
HYDRO- \\
CARBON \\
\end{tabular} \\
\hline QU ATER NARY & & PRESENT & & & \multirow{7}{*}{$\begin{array}{l}(\mathrm{H} 2) \\
(\mathrm{H} 3)\end{array}$} & \multirow{10}{*}{$\begin{array}{c}\text { DRIFT } \\
\text { SEQUENCE }\end{array}$} & \\
\hline \multirow{7}{*}{$\begin{array}{l}\mathbf{T} \\
\mathbf{E} \\
\mathbf{R} \\
\mathbf{T} \\
\mathbf{I} \\
\mathbf{A} \\
\mathbf{T} \\
\mathbf{Y}\end{array}$} & \multirow{3}{*}{ NEOGENE } & $\begin{array}{c}\text { TO } \\
\text { PLIOCENE } \\
\end{array}$ & $\begin{array}{l}\text { DENAN } \\
\text { IDJEB U } \\
\text { FM }\end{array}$ & & & & \\
\hline & & & & & & & \\
\hline & & MIOCEN E & $\begin{array}{c}\text { AF OW O } \\
\text { FM }\end{array}$ & & & & \\
\hline & \multirow{4}{*}{ PALEOGENE } & OLI GOCENE & & & & & \\
\hline & & EOCENE & OSHOSHUN FM & $=$ & & & \\
\hline & & & $\begin{array}{l}\text { IMO } \\
\text { SHALE }\end{array}$ & & & & \\
\hline & & PALEOCENE & ARAROMISHA & & $(\mathrm{H} 4)$ & & \\
\hline \multirow{11}{*}{$\begin{array}{l}\text { C } \\
\text { R } \\
\text { E } \\
\text { T } \\
\text { A } \\
\text { C } \\
\text { E } \\
\text { O } \\
\text { U } \\
\text { S }\end{array}$} & \multirow{6}{*}{ LATE } & MAESTRICHTI AN & CHENAL & 2 & & & \\
\hline & & CAM PANI AN & & & & & \\
\hline & & SANT ONIAN & & & \multirow{4}{*}{$\begin{array}{l}(\mathbf{H} 5) \\
(\mathbf{H 6}) \\
\text { TRANSITIONAL } \\
\quad \text { HABITAT }\end{array}$} & \multirow{4}{*}{$\begin{array}{l}\text { TRANSITIONAL } \\
\text { SEQUENCE }\end{array}$} & \\
\hline & & CONIACIAN & $\mathrm{AW}$ GU FM & & & & \\
\hline & & TURONI AN & $\begin{array}{l}\text { TURONI AN SST } \\
\text { ABEOKUTA }\end{array}$ & 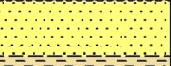 & & & \\
\hline & & CEN OM ANI AN & 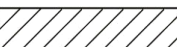 & & & & \\
\hline & \multirow{6}{*}{ LATE } & ALBI AN & ALBIAN SST & & \multirow{6}{*}{$\begin{array}{l}(\mathrm{H} 7) \\
(\mathbf{H} 8) \\
(\mathrm{H} 9) \\
\text { RIFT-VALLEY } \\
\text { HABITAT } \\
(\mathrm{H} 10) \\
\end{array}$} & TRANSGRESSIVE SEQUENCE & \\
\hline & & $\begin{array}{l}\text { APTILAN } \\
\text { BAR REMI AN }\end{array}$ & 871878 & & & \multirow{4}{*}{$\begin{array}{c}\text { RIFT } \\
\text { SEQUENCE }\end{array}$} & \\
\hline & & HA UTERRIVIAN & \multirow{4}{*}{$\begin{array}{l}\text { ISE } \\
\text { FM } \\
? ?\end{array}$} & \multirow{4}{*}{ mam } & & & \\
\hline & & VALANGINI AN & & & & & \\
\hline & & BER RIASI AN & & & & & \\
\hline IUR ASSIC & & $?$ & & & & PRE-RIFT SEQUENCA & \\
\hline PALEOZOÏC & LATE & CAM BIRI AN & BAS EM ENT & & & & \\
\hline
\end{tabular}

Figure 2. General tectono-stratigraphic chart of the Offshore Benin Basin (SAGA, 1984 modified).

\section{Stratigraphic Nomenclature Comparison}

The Mesozoic to Cenozoic basinal comparison of the stratigraphic nomenclatures of Benin and Western Nigeria offshore basins could be explained on their structural, lithologic variation and stratigraphic development. The infilling of each of these basins is dominated by the accumulation of detritus materials with minor proportion of limestone. The litho-stratigraphic succession begins with terrestrial sediments, pass through shallow marine, deep marine (with restrictive bottom circulation) to open deep marine and end with shelf sediments that are prograding southwards [9].

\subsection{Cretaceous}

The Cretaceous or Abeokuta Group (from Nigerian nomenclature), is the major object for petroleum exploration in the entire Dahomey (Benin) Embayment.

\subsubsection{Neocomian to Albian}

Neocomian to Barremian age sediments have been identified in Ise-1 and Ise-2 wells of Western Nigeria offshore basin [20] and in offshore Benin Republic [13] [24]. They consist of a sequence of folded conglomerates overlain by sandstones and sands containing kaolinitic clays intercalation. These sediments are regrouped in Ise Formation which uncomformably overlies the basement rocks in the entire Dahomey Embayment [11] [14]. Few 
details are disclosed about the Ise formation. The tentative correlation is based largely on petrographic characteristics. Ise Formation is interpreted as an Early Cretaceous rift deposit. Fluvial and lacustrine processes are the main depositional mechanism, but each basin has a different depositional history and must to be evaluated separately owing to the level of deformation of these sediments.

From wells drilled a few kilometers off the coast of Benin Republic, late Cretaceous rocks uncomformably overlie essentially non marine sandstones of early cretaceous (Albian) which in turn conformably overlie unknown thickness of non fossiliferous folded pre-Albian sediments [14]. In the Nigerian sector, Upper Albian sediments have been recognized based on palynological studies [17] [18] and conformably overlie NeocomianBarremian sediments [20]. These sediments are mainly fluviatile and deltaic type. The "Albian Sandstone" is interpreted as representing a transgressive phase with the sea advancing in a tilted and eroded rift basin after deposition of the Ise formation. The lithology of this unit is predominantly sandstone with frequent shaley and dolomitic thin beds, which distinguishes it from the overlying unit. The sandstones are white to grey to dark brown, fine to coarse grained, fair to poor sorting, feldspathic and micaceous [9]. Deposition of the "Albian sandstone," took place in an offlapping siliciclastic sedimentation cycle that prograded southwestward. According to [9], marine (Shallow Inner Neritic to Inner Neritic) environment is predominant for the upper part of the Unit and fluvial environment is predominant for the lower part below (H8) seismic horizon. The lower limit of transgressive "Albian Sandstone" is the seismic marker named Horizon 9 (H9) and its upper boundary (seismic marker H7) represents the end of the syn-rift stage. The end of the syn-rift stage is delineated by a major unconformity, which separates it from the transitional rocks of the uppermost Cenomanian to Santonian.

In summary, Neocomian to Albian age sediments representing the rifting stage, are present in the two basins. In Nigeria, they are regrouped in Ise Formation while in Benin Republic they are regrouped in two Formations: Ise Formation for the lower part and an unnamed Formation (Albian sandstones) for the upper part (Figure 2).

\subsubsection{Cenomanian to Coniacian}

It is a transitional stage during which, Abeokuta (Afowo) and Awgu Formations were deposited. The Abeokuta Formation is composed of two stratigraphic units. "Cenomanian shales" unit assemble the first deposits of this stage which are uncomformably overlie by the "Turonian sandstone" unit. This transitional stage was the period of global basin flooding of the Atlantic Ocean which begins with the deposition of organic matter rich black shales containing well-preserved planktonic foraminifera in deep waters. The deposition of the shales sequence occurs in a marginal marine to inner shelf environment. The lithology of "Turonian sandstone" consists in coarse-grained, poorly sorted sandstones containing thin shale beds. The depositional conditions are from prograding fan deltas with possible marine processes in the upper part. [9] reported that, in the Offshore Benin Basin, fluvial environment is predominant for lower part of the unit, below (H6.5) seismic horizon. The upper boundary of Abeokuta sandstones is usually picked with the influx of immature, medium and coarse predominantly non-calcareous sandstone. It is materialized by the seismic marker (H6). The lower limit is the (H7) (see Figure 2).

The Awgu Formation uncomformably overlies the "Turonian sandstone". The Formation name "Awgu" is originally used in Nigeria for a sequence of deep water shales of Turonian-Coniacian age and has been adopted by [6] for a sandy overlying the Abeokuta Sandstone. The lithology of the Formation consists in dark calcareous shales including calcareous siltstone and fine-grained sandstone beds. The Formation was deposited in an anoxic marine environment; below the Senonian unconformity which had controlled its distribution (see Figure 2). The age of the formation is Lower Senonian (Coniacian) to Maastrichtian age and it is limited at the top by Senonian Unconformity (H5) and at the base by the seismic marker (H6) [9].

In summary during this period, similar sediments gathered in Abeokuta (Afowo) and Awgu Formations were deposited in comparable environments within the two basins. The depositional process for each Formation was more extended in time within offshore Benin basin and reach Campanian period. That indicates that the Senonian unconformity took place earlier (in Santonian) in Nigeria sector and has reached westwards the Benin Republic sector in Campanian time.

\subsubsection{Campanian to Maastrichtian}

During this period, the Araromi Formation was deposited uncomformably on the Awgu Formation with the beds of carbonates representing the shallow marine facies [14]. The formation named "Npkoro Shale" is originally applied to a dark grey to blue shale unit deposited in the Anambra Basin of Nigeria. [13] correlated the Western 
Nigeria offshore unit of dark grey shale with the Nkporo Shale in the Anambra Basin. The Npkoro Shale, as it named by [13] should therefore rather be referred to as the Araromi Formation.

In Nigeria, the Nkporo Shale dates back to Late Campanian while the Araromi Shale is assigned a Campanian to Maastrichtian age. Previous study [9] indicates that, in Benin Republic, the Maastrichtian to Paleocene Araromi Shale subdivided into an upper and lower member. The boundary between the upper Araromi and lower Araromi members is announced by change in shale color. The upper Araromi Formation is of Paleocene age (Figure 2) while the lower Araromi formation is of Maastrichtian age. This Formation comprises black to dark laminated carbonaceous shales with abundant pyrite and pyritised microfauna. Limestone layers occur frequently. The Araromi formation was deposited immediately above the Senonian unconformity. His upper limit is the seismic marker named (H4). Araromi shales are clearly deep sea (Upper bathyal) shales deposited in an anaerobic restricted bottom circulation environment.

Globally, the whole section of this period has been divided in three (3) parts from top to bottom: Maastrichtian Interval; Senonian Interval and Turonian Interval. Corresponding to these three periods, are different sediments accumulated in three environments which, in general, tend to indicate a continuous invasion of a continental platform by marine waters. However, the Senonian time appeared as an unstable episode during which transitional environment prevailed between the Turonian Lowstand and the Maastrichtian Highstand sea levels events. In the Late Maastrichtian, there was a major transgression that prevailed and continued to the Paleocene. The integration of analyzed stratigraphic data give possibility to compare and attempt a correlation of the Formations identified in Benin and Western Nigeria offshore basins. The correlation is presented in Table 2. The zone colored in grey indicate periods of inconformity.

Table 2. Correlation of stratigraphic charts of Benin and Western Nigeria offshore basins (periods of main unconformities are indicated in grey).

\begin{tabular}{|c|c|c|c|c|c|}
\hline \multirow{3}{*}{\multicolumn{2}{|c|}{ AGE }} & \multicolumn{4}{|c|}{ FORMATIONS } \\
\hline & & \multicolumn{3}{|c|}{ WESTERN NIGERIA BASIN } & \multirow{2}{*}{$\begin{array}{l}\text { OFFSHORE BENIN } \\
\text { BASIN }\end{array}$} \\
\hline & & \multirow{2}{*}{\multicolumn{2}{|c|}{$\begin{array}{c}\text { Onshore } \\
\text { Omatsola \&Adegoke (1981) } \\
\text { BENIN Fm. }\end{array}$}} & Offshore & \\
\hline QUART. & PLEISTOCENE-RECENT & & & \multirow{2}{*}{ BENIN Fm. } & \multirow{2}{*}{ BENIN/IJEBU Fm. } \\
\hline \multirow{6}{*}{ 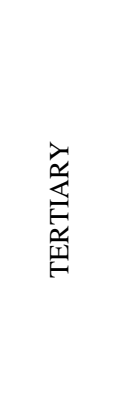 } & \multirow{5}{*}{ EOCENE-PLIOCENE } & & ILARO Fm. & & \\
\hline & & \multirow{3}{*}{\multicolumn{2}{|c|}{ OSHOSUN Fm. }} & & AFOWO Fm. \\
\hline & & & & ILARO Fm. & \\
\hline & & & & OSHOSUN Fm. & OSHOSUN Fm. \\
\hline & & \multicolumn{2}{|c|}{ AKINBO Fm. } & AKINBO Fm & \multirow{2}{*}{ IMO Fm. } \\
\hline & PALEOCENE & \multicolumn{2}{|c|}{ EWEKORO Fm. } & EWEKORO Fm. & \\
\hline \multirow{6}{*}{ 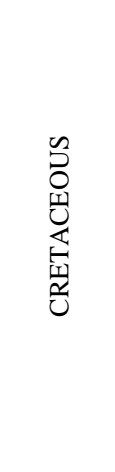 } & CAMPANIAN-MAASTRICHTIAN & \multirow{6}{*}{ 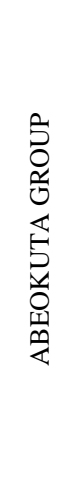 } & ARAROMI Fm. & \multirow[t]{2}{*}{ NKPORO Fm. } & \\
\hline & \multirow{3}{*}{ TURONIAN-CONIACIAN } & & \multirow{3}{*}{ AFOWO Fm. } & & AWGU Fm. \\
\hline & & & & AWGU Fm. & \multirow[b]{2}{*}{ ABEOKUTA Fm. } \\
\hline & & & & AFOWO Fm. & \\
\hline & \multirow[t]{2}{*}{ NEOCOMIAN-CENOMAIAN } & & \multirow[t]{2}{*}{ ISE Fm. } & \multirow{2}{*}{ ISE Fm. } & ALBIAN SST. \\
\hline & & & & & ISE Fm. \\
\hline
\end{tabular}




\subsection{Tertiary}

During this period, five stratigraphic units consisting mainly of marine sandstones and shales with insignificant carbonate rocks were deposited in alternating regressions and transgressions phases. These stratigraphic units are identified in the two basins and are separated by two (02) important unconformities (Table 2 and Figure 3).

\subsubsection{Paleocene to Middle Eocene}

In Nigeria coastal basin, the Paleocene-Lower Eocene Ewekoro Formation starts with the first occurrence of a grey to dark grey shale, very fissile indicating a clear lithologic break with the very glauconitic basal section of the upperlying Eocene Akinbo Formation made up of shale and clayey sequence accumulated in a shallow marine environment [28]. C2, C3, C4 generally appear for the first time with the Ewekoro shale. Fossiliferous carbonates of the Ewekoro Formation were deposited in the West and shales of the Imo Formation (lateral equivalent) were deposited in the East in a shallow marine lagoonal environment [11]. The type area of Imo Formation is in eastern Nigeria and it is the up dip equivalent of the youngest subsurface Akata Formation, the most important source rock of the Niger Delta Basin. The Akinbo Formation lays on Ewekoro Formation and is consequent to the progressive rise in sea level.

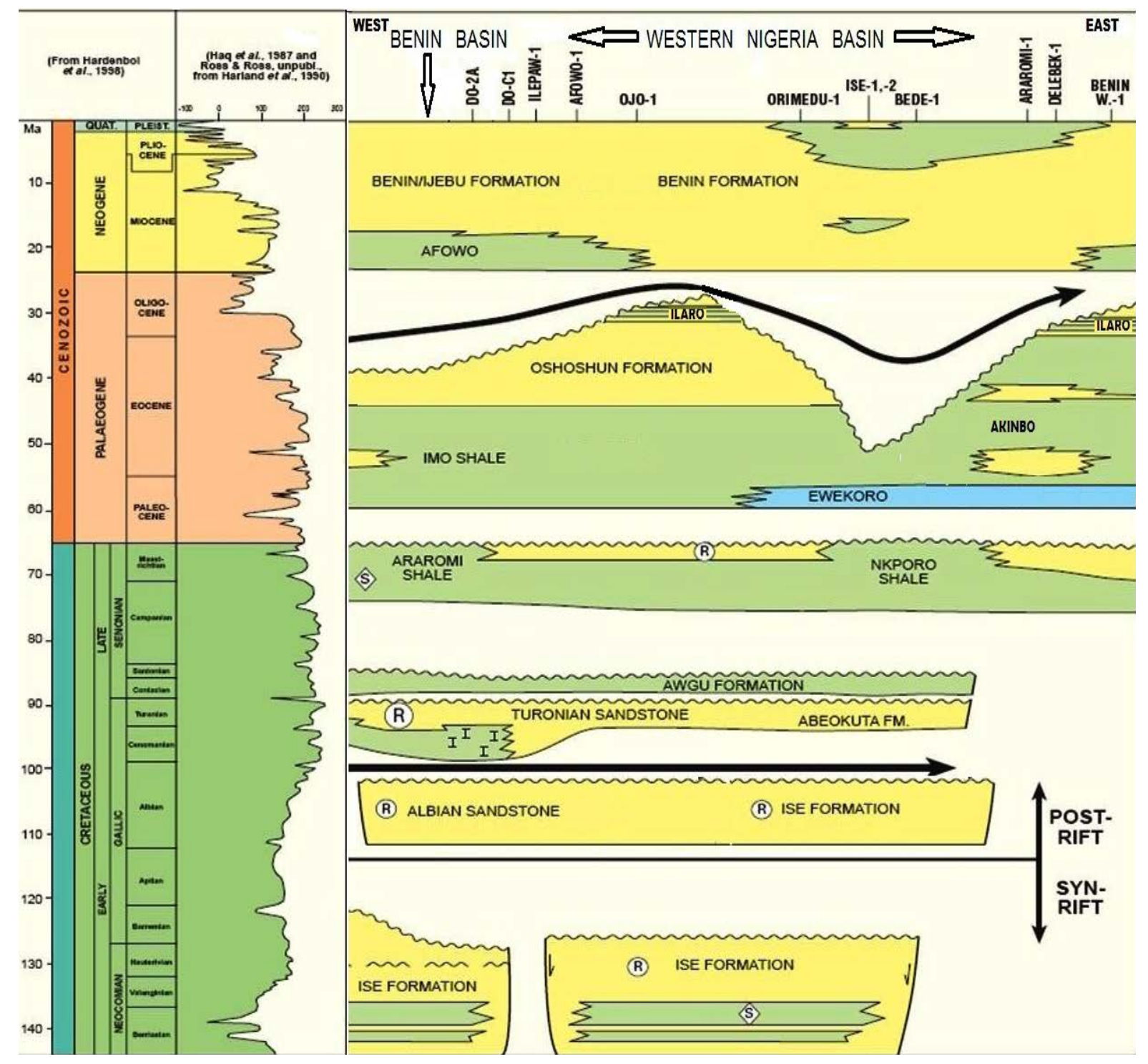

Figure 3. Schematic cross section showing lithostratigraphic units of Benin and Western Nigeria offshore basins. 
In offshore Benin, the tertiary system starts with the upper part of Araromi Formation which is uncomformably overlies by a lithostratigraphic unit called Imo Formation by [13]. The Imo Formation (equivalent of Nigerian Ewekoro and Akinbo Formations) consists of light greenish to bluish, grey to dark grey, non calcareous, firm to moderately hard shales with stringers of dark grey, microcrystalline limestone. The base of Imo Formation is the seismic horizon (H4) and the top of Imo Formation is set where the greenish shale become abundant and confirmed by Gamma Ray decrease at the same point. It has been deposited in an upper bathyal to outer sublittoral marine, well-oxygenated environment [9].

\subsubsection{Middle Eocene to Recent}

The Eocene Oshosun Formation represents an offshore sequence of marine shales and sandy shales of Middle containing abundant phosphatic material. The Oshosun formation is eroded by the Late Eocene-Oligocene regional unconformity (H3) at the Western and Eastern wedge of the Southwestern Nigeria basin. The Formation was deposited in a marine, outer sub-littoral and well oxygenated environment. In the Late Eocene, in Nigeria, the sea had withdrawn in the Dahomey Basin area leading to the deposition of the continental Ilaro Formation conformably on the Oshosun Formation. This Ilaro Formation was not identified in the offshore Benin basin. Maybe it was eroded by the well known Late Eocene-Oligocene regional unconformity (see Figure 3).

Above the Late Eocene-Oligocene regional unconformity, the uppermost lithostratigraphic unit of Benin and Western Nigeria offshore Basins are deposited. In Nigeria sector it is the Miocene to Recent Benin Formation which, as described before, consists mainly of marine shelf sands containing shale sequences. In Benin sector, above the Oligocene unconformity, a thick section of marine shale, siltstone and sandstone of Middle Miocene age was encountered offshore and named Afowo Formation by [13]. The Afowo formation is subdivided into a lower and an upper units being separated by an unconformity named Mid Miocene Unconformity (H2) which is easily picked both by seismic data and well logs. The basal limit of Afowo formation is picked by seismic horizon (H3) and the lower Afowo unit is described as a light grey siltstone grading upwards to fine grained sandstone (see Figure 2). The upper Afowo unit is a sequence of grey brown soft, sticky and silty clay interbedded with friable, coarse-grained sandstone with glauconite, pyrite and shell debris. The interbedded sands have resulted from turbidity currents. The depositional environment is interpreted as marine, outer sublittoral to upper bathyal well oxygenated environment [9].

To avoid confusion in stratigraphic harmonization of the nomenclature of these basins, the name Afowo Formation used to distinguish these sediments of Miocene age must be change as it is also applied to a very important Upper Cretaceous sandstone sequence in western Nigeria which is an oil bearing unit. It is used here as no alternative and could be change by a type area name in Benin Republic.

In both basins, the Benin (Benin-Ijebu) Formation end with recent marine shelf sediments that are prograding southwards.

\section{Conclusions}

The comparison of the stratigraphic nomenclatures of Benin and Western Nigeria offshore basins showed that these basins were initiated during the Early Cretaceous under similar tectonic conditions and continental sedimentary environments. Many similarities in lithologic variation and stratigraphic development can be approved but each basin has a different depositional history and must to be evaluated separately. The nomenclature adopted in Benin Republic is a mixed variant of Formations names of various coastal Nigeria basins. The nomenclature must be revised by using Benin type section/locality names for some particular Formations and widely proven Formations names of Nigeria for the others. This will be a more acceptable variant for the offshore Benin Basin, and will permit to avoid confusions as it is the case for the name "Afowo Formation" representing a Cretaceous sequence in Nigeria and which is use in Benin Republic to distinguish some sediments of Miocene age.

Furthermore, for a better understanding of the geological of these basins, a High Resolution Biostratigraphy summary relating to each offshore basin must be achieve for sequences correlations and entire harmonization of the stratigraphic nomenclature of these offshore basins.

\section{Acknowledgements}

Authors are very grateful to Benin Hydrocarbon Directorate, for providing borehole data from offshore Benin basin. We also thank the Department of Geology and Mineral Sciences of University of Ilorin for data provided concerning Southwestern Nigeria basins which facilitates the completion of this work. 


\section{References}

[1] Brownfield, M.E. and Charpentier, R.R. (2006) Geology and Total Petroleum Systems of the West-Central Coastal Province (7203), West Africa. U.S. Geological Survey Bulletin, 2207-C, 52 p.

[2] Bumby, A.J. and Guiraud, R. (2005) The Geodynamic Setting of the Phanerozoic Basins of Africa. Journal of African Earth Sciences, 43, 1-12. http://dx.doi.org/10.1016/j.jafrearsci.2005.07.016

[3] Burke, K., Dessauvagie, T.F.J. and Whitman, A.J. (1971) Opening of the Gulf of Guinea and Geological History of the Benue Depression and Niger Delta. Nature Physical Science, 233, 38-51. http://dx.doi.org/10.1038/physci233051a0

[4] Guiraud, R. and Maurin, J.-C. (1992) Early Cretaceous Rifts of Western and Central Africa-An Overview. Tectonophysics, 213, 153-168. http://dx.doi.org/10.1016/0040-1951(92)90256-6

[5] Almeida, F.F.M. and Black, R. (1967) Comparaison Structurale Entre le Nord-Est du Brésil et l’Ouest Africain. Symposium on Continental Drift, Montevideo.

[6] De Klasz, I. and Jan Du Chene, R. (1978) Presence of Albian-Cenomanian in South-western Nigeria and Its Paleogeographic Implications. Compte Rendu de la Société de Physique et d'Histoire Naturelle de Genève, 13, 10-15.

[7] Fadiya, S. and Ojoawo, E.A. (2015) Foraminiferal Biostratigraphy and Paleoenvironmental Analyses of Sediments from Folu-1 Borehole, Ibeju-Lekki, Lagos State, Nigeria. Ife Journal of Science, 17, 477-492.

[8] Haack, R.C., Sundararaman, P., Diedjomahor, J.O., Xiao, H., Gant, N.J., May, E.D. and Kelsch, K. (2000) Niger Delta Petroleum Systems, Nigeria. In: Mello, M.R. and Katz, B.J., Eds., Petroleum Systems of South Atlantic Margins, AAPG Memoir, 213-231.

[9] Kaki, C., d’Almeida, G.A.F., Yalo, N. and Amelina, S. (2012) Geology and Petroleum Systems of the Offshore Benin Basin (Benin), Oil \& Gas Science and Technology_Revue IFP Energies Nouvelles, 68, 363-381. http://dx.doi.org/10.2516/ogst/2012038

[10] KNOC-Benin Energy SARL (2006) Final Wellsite Geological Report. 49 p.

[11] Omatsola, M.E. and Adegoke, O.S. (1981) Tectonic Evolution and Cretaceous Stratigraphy of the Dahomey Basin. Journal of Mining and Geology, 18, 130-137.

[12] Omosanya, K.O., Akinmosin, A.A, Ikhane, P.R, Mosuro, G.O and Goodluck, I. (2012) Characterization of a Bitumen Seepage in Eastern Dahomey Basin, SW, Nigeria. Advances in Applied Science Research, 3, 2078-2089.

[13] Billman, H.G. (1978) Offshore Stratigraphy and paleontology of the Dahomey Embayment, West Africa. Proceeding in 7th African Micropaleontological Colloquium Ile-lfe (Nigeria), 21-46.

[14] Billman, H.G., (1992) Offshore Stratigraphy and Paleontology of the Dahomey Embayment, West Africa. Nigerian Association Petroleum Explorationists, 7, 121-130.

[15] Eagles, G. and Konig, M. (2008) A Model of Plate Kinematics in Gondwana Breakup. Geophysical Journal International, 173, 703-717. http://dx.doi.org/10.1111/j.1365-246X.2008.03753.x

[16] International Petroleum Limited (1991) Offshore Benin Blocs 1 et 2: Technical Evaluation. Report, 57 p.

[17] Jan Du Chene, R.E. and Salami, M.B. (1978) Palynology and Micropaleontology of the Upper Eocene of the Well Nsukka-1 (Niger Delta). Compte Rendu des Séances de la Société de Physique et d'Histoire Naturelle de Genève, 13, 5-9,

[18] Jan Duchene, R. (1998) Geology and Sequence Stratigraphy of the Benin Basin. Report ABACAN, 68 p.

[19] South Atlantic Petroleum (SAPETRO) (2010) Benin Bloc 1/Seme Petroleum System. Report, 8 p.

[20] Nton, M.E., Ikhane, P.R. and Tijani, M.N. (2009) Aspect of Rock-Eval Studies of the Maastrichtian-Eocene Sediments from Subsurface, in the Eastern Dahomey Basin Southwestern Nigeria. European Journal of Scientific Research, 25, 417-427.

[21] Adebiyi, A.O. (2015) Upper Cretaceous to Paleogene Palynosequence Stratigraphy of H-1 Well Offshore Eastern Dahomey Basin, Southwestern Nigeria. International Journal of Research and Innovations in Earth Science (IJRIES), 2, 82-88.

[22] Adebiyi, A.O. (2014) Lithostratigraphy, Palynostratigraphy and Palynofacies Indications of the Depositional Environments of Upper Cretaceous to Paleogene Sediments, Offshore Eastern Dahomey Basin, SW Nigeria. Journal of Earth Science Research, 2, 118-128. http://dx.doi.org/10.18005/JESR0204001

[23] Adeigbe, O.C., Ola-Buraimo, A.O., Moronhunkola, A.O. (2013) Palynological Characterization of the Tertiary Offshore Emi-1 Well, Dahomey Basin, Southwestern Nigeria. International Journal of Scientific \& Technology Research (IJSTR), 2, 58-70. http://www.ijstr.org

[24] Abacan-Addax Consortium (1998) Ise Hydrocarbon Potential—Benin Offshore Block 1. Report, 113 p.

[25] Hessouh, M., Marcos, I., Pereira, J.-J. and Farhangui, H.J. (1994) Hydrocarbon Prospects for Exploration and Produc- 
tion. Report, 88 p.

[26] Saga Petroleum, S.A. (1984) Benin Basin Evaluation Report. 336 p.

[27] Slansky, M. (1962) Contribution à l'étude géologique du bassin sédimentaire côtier du Dahomey et du Togo. Mém. BRGM, No. 11, 165 p.

[28] Moulin, M., Aslanian, D. and Unternehr, P. (2010) A New Starting Point for the South and Equatorial Atlantic Ocean. Earth-Science Reviews, 98, 1-37. http://dx.doi.org/10.1016/j.earscirev.2009.08.001 